\title{
Filsafat Pendidikan dan Perkembangannya: Kajian Bibliometrik berdasarkan Database Scopus
}

\author{
Roni Herdianto *, Nia Windyaningrum *, Betty Masruroh *, Mohamad Arif \\ Setiawan** \\ * Universitas Negeri Malang \\ ** Politeknik Negeri Malang
}

\begin{tabular}{l} 
INFO ARTIKEL \\
\hline Riwayat Artikel: \\
Diterima: 02-02-2021 \\
Disetujui: 03-03-2021 \\
\hline
\end{tabular}

\section{Kata kunci:}

Filsafat pendidikan Analisis bibliometric Software VOSviewer SEforRA

\begin{abstract}
ABSTRAK
Abstract: Educational philosophy is at the heart of the development of the world of education in general. Apart from playing a very fundamental role, educational philosophy also provides a framework for the goals and objectives of the institution, the subjects to be taught, teaching and learning experiences, and assessment methods. The research objective is to provide an overview of the educational philosophy research literature based on bibliometric analysis of a number of journal articles published in the Scopus database and to identify scientific gaps as a reference for further research. The method used is bibliometric analysis with the help of VOSviewer and SEforRA software. The results showed an increasing trend in research on educational philosophy and found several topics / keywords that could be used as the basis for further research. The conclusion is that bibliometric analysis provides information and knowledge about the development of educational philosophy research for the possibility of further new research
\end{abstract}

\begin{abstract}
Abstrak: Filsafat pendidikan merupakan jantung dari pengembangan dunia kependidikan secara umum. Selain memegang peran yang sangat mendasar, filsafat pendidikan juga memberikan kerangka kerja untuk tujuan dan sasaran lembaga, mata pelajaran yang akan diajarkan, pengalaman belajar mengajar, dan metode penilaian. Tujuan penelitian adalah memberikan gambaran umum tentang literatur penelitian filsafat pendidikan berdasarkan analisis bibliometrik dari sejumlah artikel jurnal yang dipublikasikan di database scopus dan untuk identifikasi kesenjangan ilmiah sebagai acuan untuk penelitian selanjutnya. Metode yang digunakan adalah analisis bibliometrik dengan dibantu software VOSviewer dan SEforRA. Hasil penelitian menunjukkan tren peningkatan penelitian tentang filsafat pendidikan dan ditemukan beberapa topik/kata kunci yang dapat dijadikan dasar penelitian selanjutnya. Simpulannya adalah analisis bibliometrik memberikan informasi dan pengetahuan tentang perkembangan penelitian filsafat pendidikan untuk kemungkinan dilakukan penelitian baru selanjutnya.
\end{abstract}

\section{Alamat Korespondensi:}

Roni Herdianto

Pascasarjana

Jl. Semarang No.5, Sumbersari, Kec. Lowokwaru, Kota Malang, Jawa Timur 65145

E-mail: roni.herdianto@um.ac.id 
PENDAHULUAN

\section{Filsafat Pendidikan}

Filsafat merupakan teori umum dari pendidikan, landasan dari semua pemikiran mengenai pendidikan (Dewey, 1944). Filsafat pendidikan adalah filsafat ilmu-ilmu khusus (philosophy of spesific science) yang mendalami esensi penerapan dalam pendidikan (Mudyahardjo, 2008). Materi yang dibahas antara lain adalah sasaran, konteks, model, hasil, dan prinsip pendidikan (Mudyahardjo, 2008). Metode yang dilaksanakan adalah mengkaji secara kritis metode dan makna pendidikan (Mudyahardjo, 2008). Filsafat pendidikan mencari jalan untuk memikirkan secara mendalam tentang problematika pendidikan (Muhmidayeli, 2011). Contoh permasalahan yang dikritisi secara aktual adalah hubungan antara guru/dosen dan siswa/mahasiswa dalam pendidikan di sekolah atau perguruan tinggi (Hidayat, 2013). Salah satu yang sering dibahas saat ini adalah tentang pendidikan adalah faktor pengalaman (Dewey, 2008). Filsafat pendidikan berupaya merespon masalah kebijakan pendidikan, sumber daya manusia, konsep kurikulum dan pembelajaran dan faktor-faktor pendidikan lainnya (Kuswana, 2013). Penelitian bidang filsafat ilmu dengan lingkup yang khusus yang dilakukan peneliti luar Indonesia, antara lain oleh Beatty et al. (2020) yang melakukan riset tentang eksplorasi hubungan antara filsafat pengajaran, filsafat pendidikan, dan filsafat. Sementara Kelam dan Rašić (2020) melakukan penelitian tentang Pengaruh Pemikiran Filsafat Schopenhauer dan Nietzsche pada Filsafat Pendidikan dan Pesimisme Pendidikan, yang lainnya adalah emansipasi sebagai subjekifikasi: Bacaan realis kritis dari filosofi pendidikan Biesta diteliti oleh Christodoulou (2020). Sedangkan Jarrah et al. (2020) meneliti penerapan pragmatisme dan filosofi pendidikan John Dewey di sekolah dasar Emirat: Kasus guru matematika dan sains. Dengan kompleksnya cakupan keilmuan filsafat pendidikan, diperlukan metode yang sistematis dan akurat untuk selalu mengikuti perkembangan penelitian tentang filsafat pendidikan.

\section{Analisis Bibliometrik}

Analisis bibliometrik memberikan metode yang akurat dan objektif untuk mengukur kontribusi sebuah artikel bagi kemajuan pengetahuan, dan merupakan alat yang sering digunakan untuk menganalisis tren dan kinerja pada subjek tertentu (Yang et al., 2013). Analisis bibliometrik digunakan untuk lebih memahami evolusi dalam studi filsafat pendidikan pada komunitas akademis, dengan harapan dapat menemukan research gap dan novelty sebagai dasar pijakan penelitian selanjutnya.

Penelitian sebelumnya menyebutkan bahwa studi bibliometrik pernah dilakukan oleh Institut Astrobiologi NASA dalam penelitian di bidang astrobiologi interdisipliner kolaboratif (Taşkın \& Aydinoglu, 2015). Literature riview bibliometrik digunakan dalam konsep green manufacturing (Setyaningsih et al., 2018). Analisis bibliometik pernah dilakukan dalam penelitian big data internasional (Ye, 2018). Penelitian pembangunan berkelanjutan pada industry 4.0 dengan analisis bibliometrik pernah dilakukan oleh Sierra-Henao et al. (2020). Di bidang manajemen dan organisasi dengan metode bibliometrik diteliti oleh Zupic \& Čater (2015). Sementara itu untuk mengetahui tren penelitian osmosis di bagian desalinasi dan pengolahan air limbah selama dekade terakhir dilakukan oleh Ang et al. (2019). Meskipun penelitian tentang analisis bibliometrik sudah banyak dilakukan dalam banyak bidang lain, tetapi belum ada yang melakukan dalam bidang filsafat pendidikan. Akan sangat menarik jika dikaji analisis bibliometrik dalam filsafat pendidikan.

Tujuan dari penelitian ini adalah untuk memberikan gambaran umum (overview) tentang literatur penelitian filsafat pendidikan berdasarkan analisis bibliometrik dari sejumlah artikel jurnal yang dipublikasikan di database scopus dengan tujuan untuk mengidentifikasi kesenjangan ilmiah (scientific gaps) sebagai acuan untuk penelitian selanjutnya.

\section{METODE}

Metode yang digunakan dalam riset ini terdiri dari lima tahapan sebagai berikut (Tranfield et al., 2003) (Gambar 1).

\section{Menentukan kata kunci pencarian}

Kata kunci yang dijadikan acuan dalam penelitian ini adalah "educational philosophy". Selain kata kunci, tahun terbit artikel juga dijadikan pertimbangan dalam menambang artikel. Terdapat dua kali penambangan 
artikel dengan dua tools yang berbeda. Tools yang pertama (Publish or Perish 7) dengan mode pencarian tidak ada batasan tahun terbit dan tools kedua (SEforRA)(Sidiq et al., 2020) dengan mode pencarian batasan tahun terbit antara 2015-2020. Platform database artikel jurnal yang dipilih adalah Scopus. Artikel dari database Scopus dijadikan dasar mendapatkan artikel dengan kualitas baik. Scopus merupakan database artikel multidisiplin ilmu yang mengumpulkan berbagai artikel dari jurnal-jurnal bereputasi internasional yang sudah diterbitkan oleh Elsevier, Springer, Wiley, Taylor \& Francis, Emerald, Nature dll.

\section{Hasil pencarian awal}

Hasil pencarian dengan tools Publish or Perish 7 dan SEforRA memberikan data berturut-turut adalah sebanyak 200 artikel jurnal dengan tahun terbit antara 1938-2020 dan 1500 artikel jurnal dengan tahun terbit antara 2015-2020. Data artikel dalam format RIS dan csv.

\section{Menyaring (filtering) data hasil pencarian untuk disesuaikan dengan kebutuhan}

Data artikel yang terkumpul masih dalam format RIS file dan csv file, sehingga csv file perlu dirubah ke dalam format xlsx file agar dapat diolah dengan mudah di microsoft excel, sedangkan untuk membaca RIS file diperlukan reference management software Mendeley. Selanjutnya data jurnal dalam format xlsx file diolah dan disaring disesuaikan dengan kebutuhan analisis.

\section{Mengumpulkan dan menyusun data statistik hasil pencarian}

Setelah data artikel disaring dan dihasilkan data hasil olahan antara lain evolusi artikel lima tahun terakhir (2015-2020), Top 10 artikel dengan sitasi terbanyak, Top 10 publisher dan jurnal, serta data lainnya yang diperlukan dalam analisis.

\section{Melakukan analisis data (bibliometrik)}

Analisis bibliometrik dilakukan dengan menggunakan software VOSviewer. VOSviewer memiliki kemampuan bekerja secara efisien dengan data yang sangat banyak dan menyediakan fasilitas visualisasi data yang menarik dan komunikatif, analisis dan investigasi data (N J van Eck \& Waltman, 2010). Kemudian VOSviewer juga dapat menyusun publication maps, author maps, atau journal maps berbasis co-citation networks atau menampilkan keyword maps berdasarkan shared networks (Nees Jan van Eck \& Waltman, 2010, 2014).

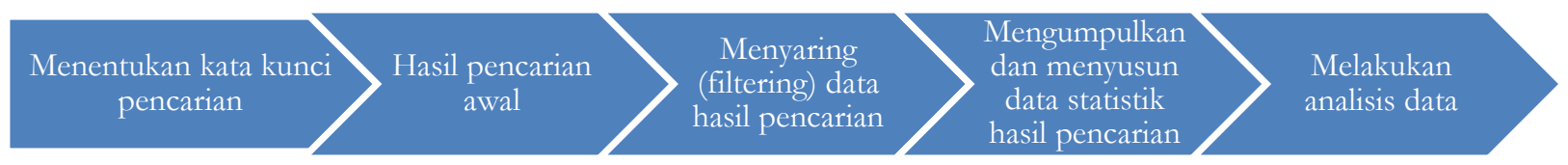

Gambar 1. Lima langkah metode analisis bibliometric.

\section{HASIL}

\section{Evolusi Publikasi Filsafat Pendidikan}

Data perkembangan artikel filsafat pendidikan yang dihasilkan dalam penelitian ini diambil dari database Scopus-Elsevier. Berdasarkan database yang diambil dari Publish or Perish (PoP) tools (Gambar 2) dengan rincian sebagai berikut: kata kunci yang digunakan adalah educational philosophy; tahun pencarian data tidak dibatasi dan secara otomatis PoP memberikan rentang tahun penerbitan antara 1938 s.d. 2020; sumber data adalah scopus; jumlah paper yang dapat diambil 200 artikel. Artikel tertua berdasarkan data tersebut adalah artikel terbitan tahun 1938 dengan judul The educational philosophy of the teacher of speech ditulis oleh A. Craig Baird pada Quarterly Journal of Speech Vol. 24 No. 4 halaman 545-553. Baird (1938) menyebutkan bahwa semangat dari filosofi pendidikan adalah ekperimen dan evaluasi serta kurikulum harus selalu terkait dengan pengalaman siswa saat ini dan nanti. 


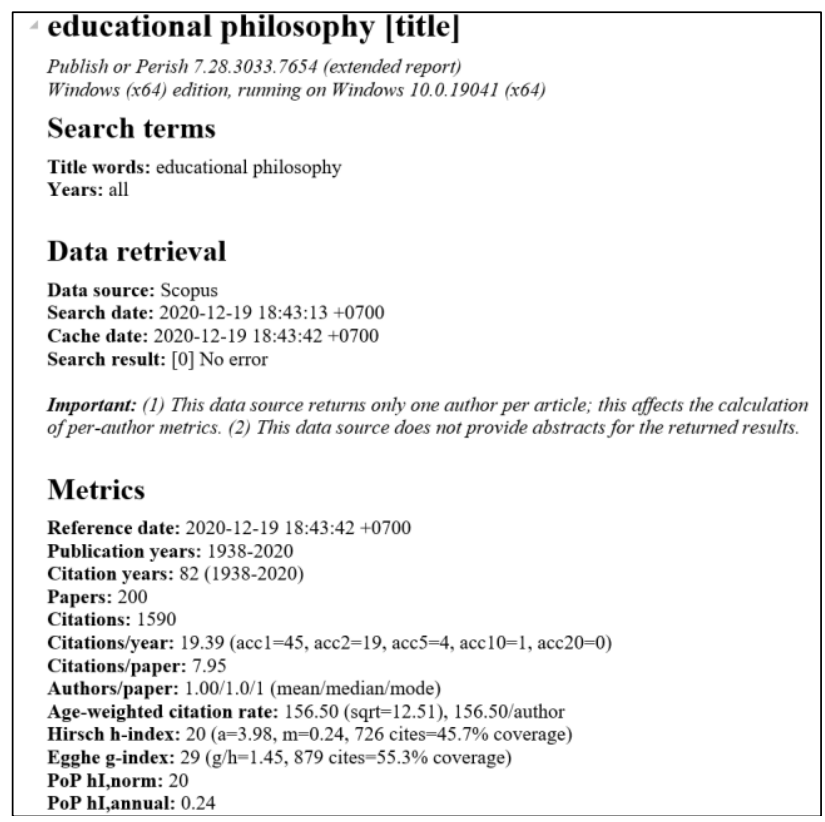

Gambar 2. Metadata artikel

Jumlah publikasi artikel filsafat pendidikan dari tahun 1938 s.d 2020 rata-rata mengalami peningkatan (Gambar 3); dengan jumlah artikel terbanyak diterbitkan pada tahun 2014 dan 2016 sejumlah 12 artikel dan jumlah artikel paling sedikit diterbitkan pada tahun 1938 sejumlah 1 artikel. Berdasarkan gambar 3, pada rentang 1938 s.d 2000an jumlah artikel filsafat pendidikan yang dipublikasikan mengalami peningkatan yang kurang signifikan. Setelah tahun 2000 ke atas internet mulai digunakan secara meluas dan bertambahnya kemudahan akses (Wikipedia, 2020). Secara signifikan kenaikan jumlah artikel yang dipublikasikan linier dengan global internet traffic dan pengunaan data/bulan. Infrastuktur dan media yang semakin baik memicu peningkatan publikasi, apalagi didorong gerakan akses terbuka (About Sherpa Romeo - v2.Sherpa, n.d.; Budapest Open Access Initiative | Ten Years on from the Budapest Open Access Initiative: Setting the Default to Open, n.d.; Directory of Open Access Journals (DOAJ), n.d.; Björk, 2017; Tupan, 2016) di seluruh dunia menyebabkan secara masif peningkatan publikasi artikel ilmiah.

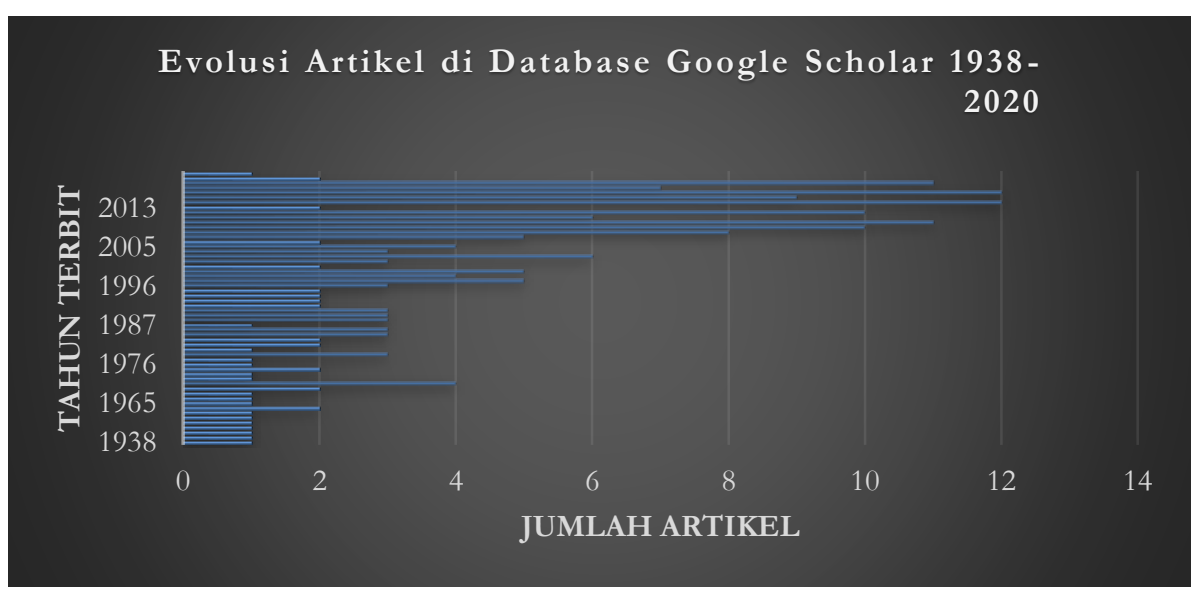

Gambar 3. Grafik evolusi artikel di database google scholar 1938-2020

Tidak jauh berbeda dari data yang diperoleh dari Google scholar; database dari Scopus dari tahun 2015 s.d 2020, sejumlah 1500 artikel filsafat pendidikan juga menunjukkan tren yang meningkat (Gambar 4) dengan jumlah artikel terbit terbanyak pada tahun 2018 (362 artikel) dan jumlah terendah artikel terbit pada tahun 2015 (189 artikel). Terjadi peningkatan jumlah terbitan dari tahun 2019 (191 artikel) s.d 2020 (302 artikel), meskipun 
jika dibandingkan pada tahun 2018 (362 artikel) mengalami penurunan jumlah terbitan artikel disebabkan terjadinya wabah Covid 19 yang melanda seluruh dunia.

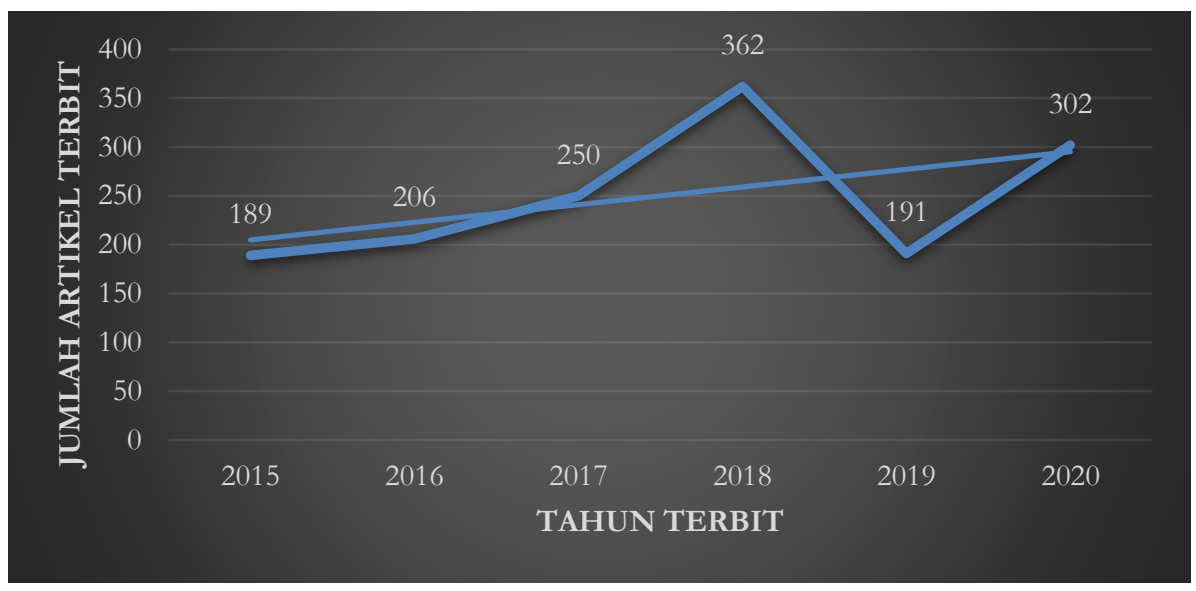

Gambar 4. Evolusi artikel di database scopus 2015-2020

Berdasarkan Tabel 1, jumlah artikel terbanyak yang diterbitkan yang masuk dalam scimago journal rank adalah pada tahun 2018 sebanyak 319 artikel yang terdistribusi di $\mathrm{Q} 1=319 ; \mathrm{Q} 2=0 ; \mathrm{Q} 3=4 ; \mathrm{Q} 4=0 ; \mathrm{NQ}=0 ; \mathrm{NI}=39$, sedangkan tahun 2015 merupakan jumlah artikel terbit paling sedikit (189 artikel) dengan distribusi di masingmasing Q1 s,d NI berturut-turut adalah 160, 4, 0, 0, 0, 25 artikel. Jumlah artikel yang masuk dalam Quartile (Q) 1 Scimago journal rank adalah 831 (55\%) dari 1500 artikel yang terbit dari tahun 2015 s.d 2020. Hal ini menunjukkan bahwa artikel-artikel yang ditulis dengan tema filsafat pendidikan merupakan artikel-artikel dengan kualitas tulisan sangat baik. Kalau dilihat lebih detail pada tahun 2018 merupakan puncak jumlah artikel terbanyak yang masuk dalam Q1 dengan total jumlah artikel 319 artikel terpublikasi.

Tabel 1. Rangking di scimago journal

\begin{tabular}{|c|c|c|c|c|c|c|c|}
\hline Year & \multicolumn{6}{|c|}{ Schimago Journal Rank } & \multirow[t]{2}{*}{ Sub Total } \\
\hline & Q1 & Q2 & Q3 & Q4 & NQ & NI & \\
\hline 2015 & 160 & 4 & 0 & 0 & 0 & 25 & 189 \\
\hline 2016 & 10 & 161 & 2 & 0 & 0 & 33 & 206 \\
\hline 2017 & 204 & 6 & 0 & 1 & 0 & 39 & 250 \\
\hline 2018 & 319 & 0 & 4 & 0 & 0 & 39 & 362 \\
\hline 2019 & 63 & 6 & 0 & 0 & 0 & 122 & 191 \\
\hline 2020 & 75 & 192 & 0 & 5 & 1 & 29 & 302 \\
\hline \multicolumn{7}{|c|}{ Total Result } & 1500 \\
\hline
\end{tabular}

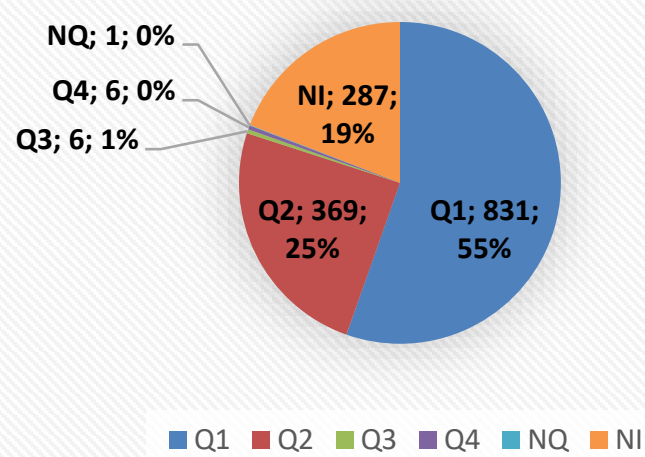

Gambar 5. Diagram distribusi quartil (Q) di Scimago (2015-2020) 


\section{Peringkat Sepuluh Besar (Top 10)}

Merujuk pada hasil yang sudah diperoleh dari analisis bibliografi terdapat beberapa temuan sebagai berikut. (1) Oktadiana dan Chon merupakan penulis paling banyak disitasi, dengan 5 sitasi. (2) Terbit di jurnal Annals of Tourism Research, 57, 236-239 pada tahun 2016 dengan judul Educational philosophy: Grounding the tourism curriculum. (3) Secara ringkas berisi analisis lebih lanjut tentang desain kurikulum pariwisata dan perhotelan yang berdasarkan filosofis sebagai jantung pengembangan kurikulum. Pertimbangan filosofis memberikan kerangka kerja untuk tujuan dan sasaran lembaga, mata pelajaran yang akan diajarkan, pengalaman belajar mengajar, dan metode penilaian.

Diantara jurnal yang masuk peringkat sepuluh besar, 90\% diterbitkan oleh jurnal Educational Psychology. Jurnal tersebut menduduki peringkat ke 2 s.d ke 10, yang diterbitkan antara tahun 2018-2020. Sementara jurnal Annals of Tourism Research hanya menempatkan satu artikelnya di Best Top 10. Kedua jurnal masuk dalam Scimago Journal \& Country Rank pada Q1 (Gambar 6).

Tabel 2. Top 10: penulis, artikel, jurnal, sitasi

\begin{tabular}{|c|c|c|c|c|c|c|}
\hline No & Authors & Title & Year & Journal & Type & Cited \\
\hline 1 & Oktadiana, H.Chon, K. & $\begin{array}{l}\text { Educational philosophy: } \\
\text { Grounding the tourism } \\
\text { curriculum }\end{array}$ & 2016 & $\begin{array}{l}\text { Annals of } \\
\text { Tourism } \\
\text { Research, 57, } \\
236-239\end{array}$ & Journal & 5 \\
\hline 2 & Chen, C.Ye, S.Hangen, E & $\begin{array}{l}\text { Predicting achievement } \\
\text { goals in the East and } \\
\text { West: the role of grit } \\
\text { among American and } \\
\text { Chinese university } \\
\text { students }\end{array}$ & 2018 & $\begin{array}{l}\text { Educational } \\
\text { Psychology, } \\
\text { 38(6), 820-837 }\end{array}$ & Journal & 0 \\
\hline 3 & Lanford, M & $\begin{array}{l}\text { Institutional competition } \\
\text { through performance } \\
\text { funding: A catalyst or } \\
\text { hindrance to teaching } \\
\text { and learning? }\end{array}$ & 2020 & $\begin{array}{l}\text { Educational } \\
\text { Philosophy and } \\
\text { Theory, 1-13 }\end{array}$ & Journal & 0 \\
\hline 4 & Means, A.J.Sojot, A.N.Ida, Y.Hardt, M. & $\begin{array}{l}\text { A dialogue with Michael } \\
\text { Hardt on revolution, joy, } \\
\text { and learning to let go }\end{array}$ & 2020 & $\begin{array}{l}\text { Educational } \\
\text { Philosophy and } \\
\text { Theory, 1-14 }\end{array}$ & Journal & 0 \\
\hline 5 & Lin, C.Jackson, L. & $\begin{array}{l}\text { Sinophobia in Hong Kong } \\
\text { News Media. }\end{array}$ & 2020 & $\begin{array}{l}\text { Educational } \\
\text { Philosophy and } \\
\text { Theory, 1-16. }\end{array}$ & Journal & 0 \\
\hline 6 & Chen, H.Peng, Z & $\begin{array}{l}\text { Discontinuous learning } \\
\text { through destructive } \\
\text { experiences: A 'change' } \\
\text { approach to catastrophe } \\
\text { education in eco- } \\
\text { pedagogy. }\end{array}$ & 2020 & $\begin{array}{l}\text { Educational } \\
\text { Philosophy and } \\
\text { Theory, 52(13), } \\
\text { 1409-1420. }\end{array}$ & Jurnal & 0 \\
\hline 7 & Peters, M.A.Green, B.Yang, H & $\begin{array}{l}\text { Cryptocurrencies, China's } \\
\text { sovereign digital currency } \\
\text { (DCEP) and the US } \\
\text { dollar system }\end{array}$ & 2020 & $\begin{array}{l}\text { Educational } \\
\text { Philosophy and } \\
\text { Theory, 1-7. }\end{array}$ & Journal & 0 \\
\hline 8 & Sardoč, M. & Introduction & 2020 & $\begin{array}{l}\text { Educational } \\
\text { Philosophy and } \\
\text { Theory, 1-2 }\end{array}$ & Journal & 0 \\
\hline 9 & Ogunniran, M. & $\begin{array}{l}\text { The opening-up of } \\
\text { education in the new era: } \\
\text { Communist Party of } \\
\text { China (CCP) and the } \\
\text { Central Committee }\end{array}$ & 2020 & $\begin{array}{l}\text { Educational } \\
\text { Philosophy and } \\
\text { Theory, 1-7. }\end{array}$ & Journal & 0 \\
\hline 10 & Shabani Varaki, B.Mohammadi Chaboki, R. & $\begin{array}{l}\text { Iranian philosophy of } \\
\text { education. }\end{array}$ & 2020 & $\begin{array}{l}\text { Educational } \\
\text { Philosophy and } \\
\text { Theory, 1-6. }\end{array}$ & Journal & 0 \\
\hline
\end{tabular}




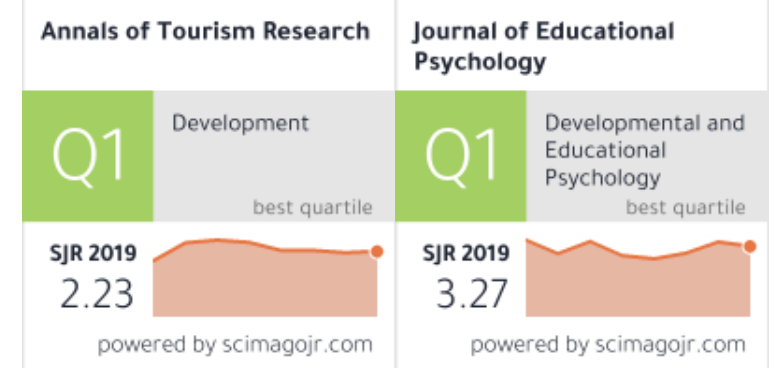

Gambar 6. Scimago journal \& country rank

\section{Analisis Co-Authorship}

Analisis Co-Authorship berguna untuk mencari hubungan berbagai penelitian berdasarkan dokumen penelitian yang dihasilkan oleh peneliti. Jaringan co-authorship merupakan suatu alat untuk mengungkap arah kolaborasi dan mengidentifikasi peneliti dan institusi yang memimpin penelitian (E Fonseca et al., 2016), analisis jaringan co-authorship dapat membantu mengatasi, memberikan kontribusi yang substansial untuk pengembangan keilmuan (Morel et al., 2009).

Setelah proses penambangan data artikel dengan software SEforRA selesai dilakukan, maka akan didapatkan (didownload) file dengan format RIS yang kemudian akan menjadi masukan data yang diminta oleh VOSviewer untuk melakukan analisis bibliometrik. Salah satu analisis bibliometrik yang akan dikerjakan adalah analisis co-authorship.

Hasil analisis co-authorship yang sudah dilakukan VOSviewer adalah sebagai berikut (Gambar 7). Secara umum dapat dibaca relasi antara penulis satu dengan yang lainnya adalah adanya garis yang menghubungkan antara satu nama penulis dengan nama penulis lainnya. Semakin banyak garis yang menghubungkan sebuah nama dengan nama lainnya menggambarkan bahwa penulis tersebut telah bersama-sama berkolaborasi menulis/melakukan penelitian di dalam sebuah artikel/penelitian yang sama (van Eck, Nees Jan, \& Waltman, 2013). Sebagai contoh adalah Peters merupakan penulis yang memiliki kolaborasi menulis/meneliti terbanyak yang ditunjukkan tebal node dan banyaknya garis yang menghubungkan namannya dengan nama penulis lainnya. Lebih detail akan diterangkan sebagai berikut.

a. Gambar 7a: hubungan kolaboratif antara penulis satu dengan lainnya dalam sebuah jaringan yang saling terhubung. Dapat dilihat terdapat tujuh kluster penulis yang dihasilkan dari analisis co-authorship (a-d-e). Tujuh kluster tersebut digambarkan dengan adanya perbedaan warna. Setiap warna mewakili sebuah kluster tertentu (van Eck, Nees Jan, \& Waltman, 2013). Kluster ini juga menunjukkan ke arah mana (topik) penelitian dilakukan.

b. Gambar 7b: menggambarkan perjalanan waktu publikasi dari tahun 2015 s.d 2020; ditunjukkan dengan warna semakin kuning maka tahun publikasi semakin baru, sebaliknya dengan warna semakin gelap kebiruan menunjukkan tahun publikasi semakin lama (van Eck, Nees Jan, \& Waltman, 2013). Penulis dengan artikel terbaru dipublikasikan oleh Benjamin Green.

c. Gambar 7c: merupakan density publikasi dari penulis, semakin jelas warna kuningnya menunjukkan bahwa kluster penulis tersebut mempunyai banyak artikel yang dipublikasikan, sementara dengan warna semakin pudar maka semakin sedikit artikel yang dipublikasikan (van Eck, Nees Jan, \& Waltman, 2013). Penulis dengan jumlah publikasi terbanyak oleh Michael A Peters.

d. Gambar 7d-e: tujuh kluster yang terbentuk dengan masing-masing kelompok penulis di dalamnya beserta kelompok warna yang mewakili setiap kluster. Kluster 1 (merah) dengan 8 nama; kluster 2 (hijau) dengan 6 nama; kluster 3 (biru) dengan 5 nama; kluster 4 (kuning) dengan 5 nama; kluster 5 (ungu) dengan 4 nama; kluster 6 (cyan) dengan 2 nama; kluster 7 (orange) dengan 2 nama. 


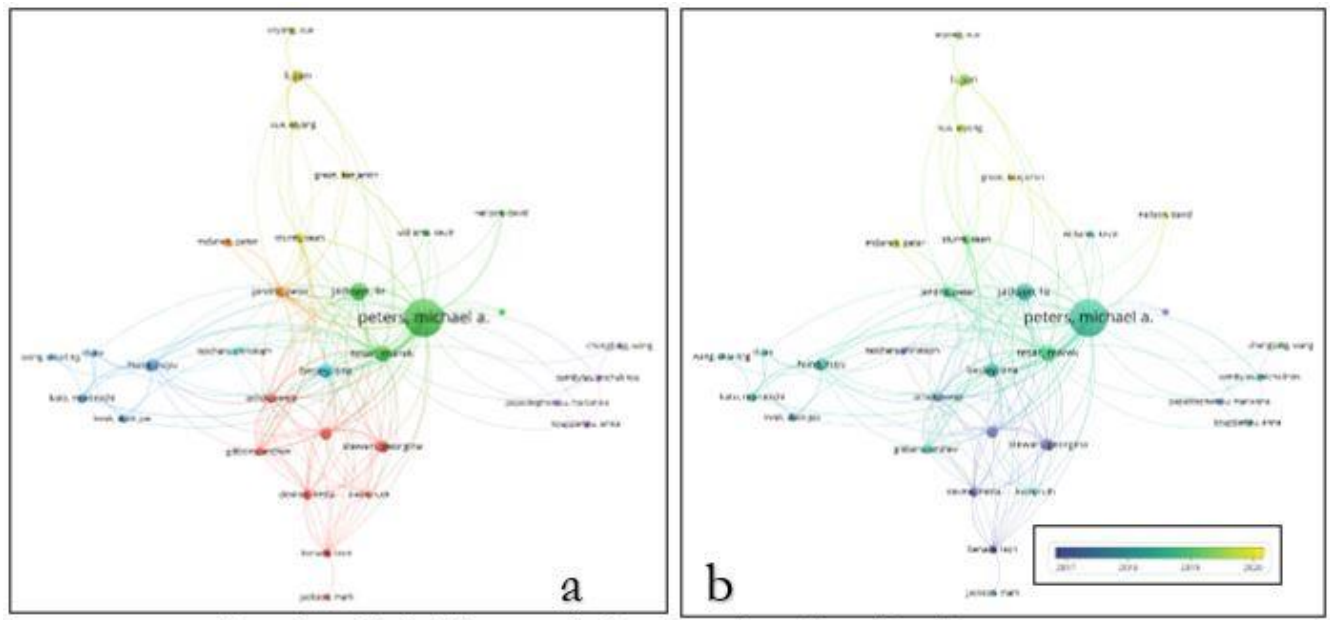

Gambar 7a-b. Network dan overlay visualization
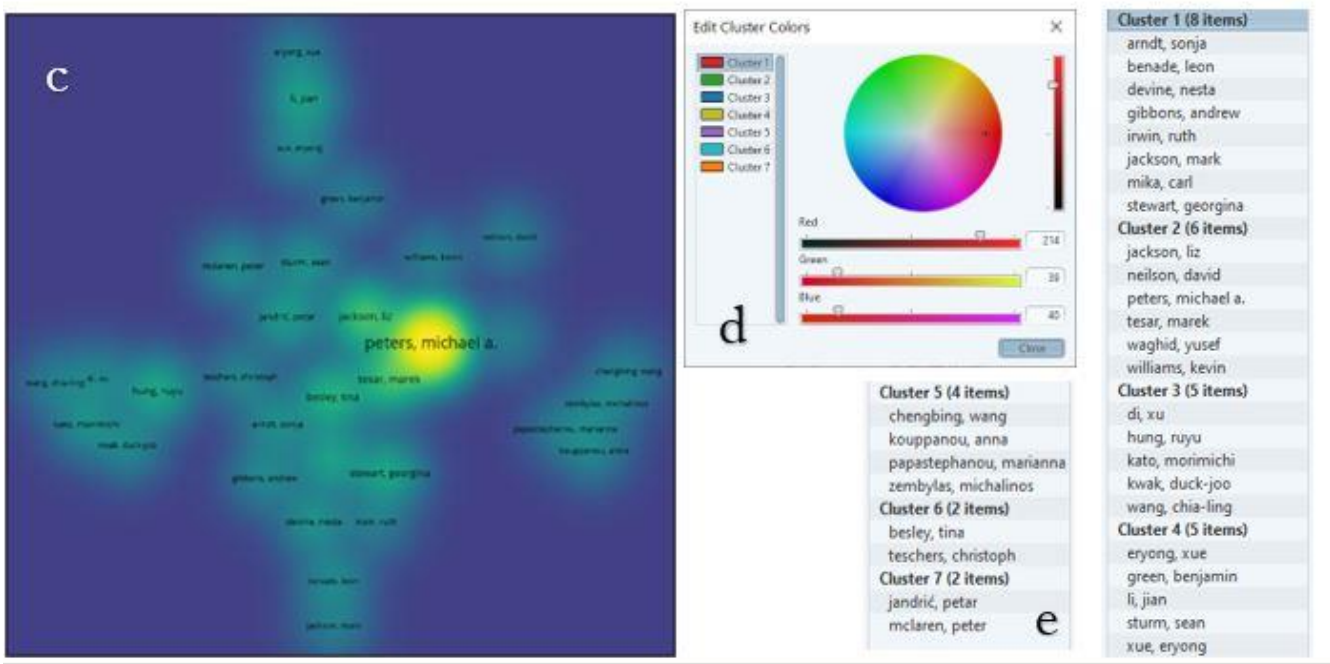

Gambar 7c-d-e. Density visualization, cluster colors, dan cluster

\section{Analisis Co-Word}

Hasil analisis co-word berdasarkan kata kunci menjadi acuan pemetaan co-occurrence terhadap istilahistilah penting atau spesifik yang terdapat dalam artikel tertentu. Di dalam bibliometrika, pemetaaan ilmu pengetahuan adalah metode visualisasi sebuah bidang ilmu. Visualisasi dilakukan dengan menciptakan peta lanskap yang dapat menampilkan topik dari ilmu pengetahuan (Royani et al., 2013).

VOSviewer akan menampilkan istilah-istilah yang berhubungan dengan filsafat pendidikan sebanyak 74 terms dengan minimum 10 kali kejadian muncul. Secara default VOSviewer akan menampilkan 60\% (van Eck, Nees Jan, \& Waltman, 2013) dari 74 terms tetapi dalam analisis ini ditentukan 74 terms akan dimunculkan semua. Sepuluh istilah terbanyak yang sering muncul adalah education (434), philosophy (284), educational philosophy (77), postmodernism (67), study (57), development (54), knowledge (49), perspective (48), pedagogy (46), practice (46); sedangkan istilah yang paling jarang muncul adalah corrigendum (10). 

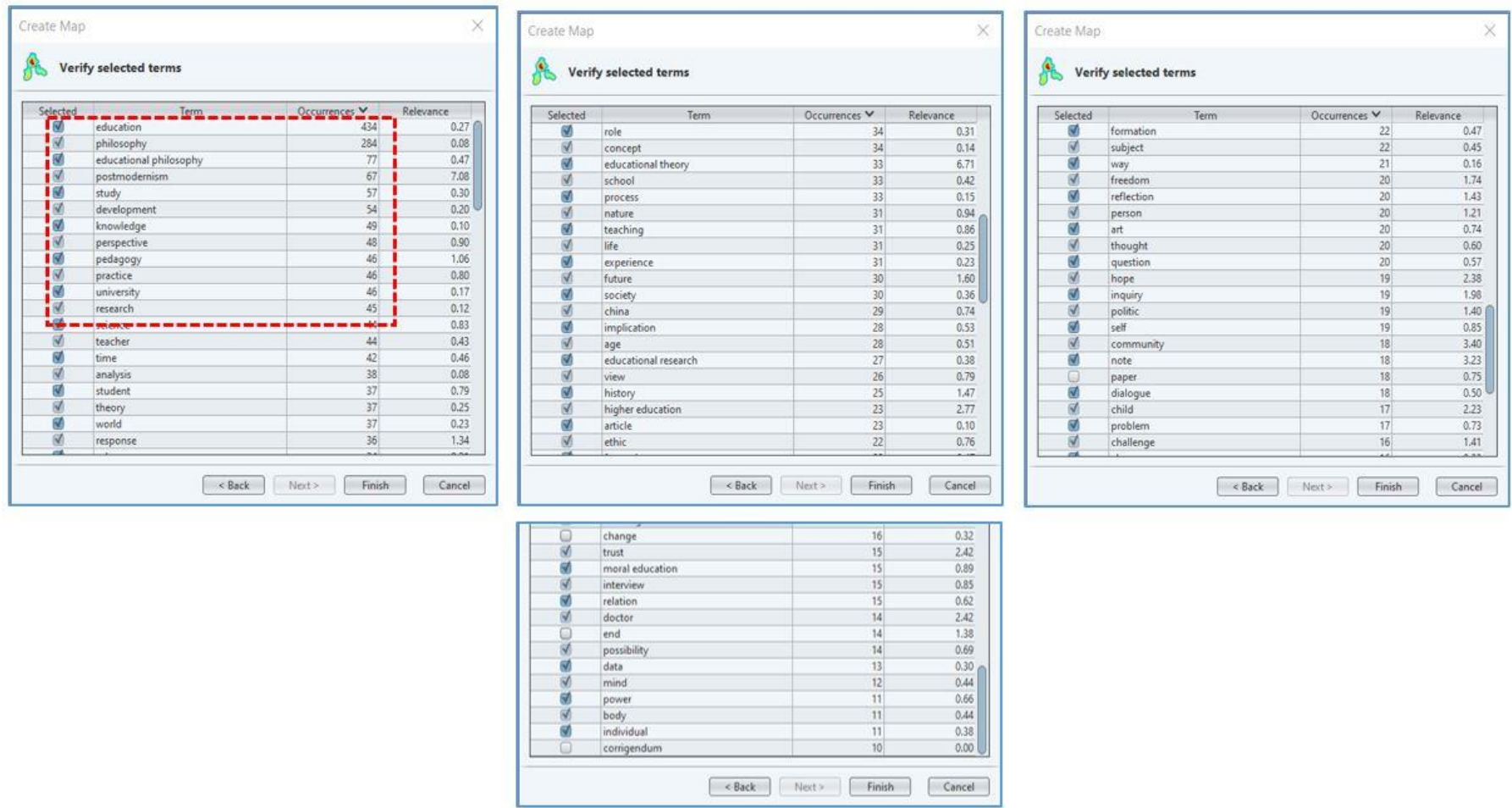

Gambar 8. Istilah/kata kunci yang sering muncul

Setelah istilah/kata kunci dimunculkan VOSviewer, kemudian VOSviewer menampilkan network visualization berdasarkan istilah-istilah/kata kunci tersebut (Gambar 9). Beberapa temuan penting yang dibahas dalam penelitian ini adalah sebagai berikut. (1) Educational philosophy dan philosophy adalah istilah yang sering digunakan dalam penelitian filsafat pendidikan yang ditandai dengan node yang besar dibandingkan dengan istilah lain. (2) Terdiri dari 13 kluster istilah yang ditandai dengan warna-warna yang berbeda dari setiap kluster (Gambar 10). (3) Contoh pengggunaan network visualization; terlihat (Gambar 9) istilah yang diwakili dengan notasi 1,2,3, 4, dan 5. Dalam mencari novelty dari sebuah penelitian diperlukan suatu hal yang baru dan belum pernah terhubung sama sekali antara istilah-istilah dalam jaringan tersebut. Istilah yang diberi notasi 1 s.d 5 sebelumnya merupakan lima kata kunci yang terpisah dan belum pernah terhubung sama sekali. Ketika diantara salah 1 s.d 5 dari notasi itu dihubungkan dalam suatu penelitian yang sama, maka artinya terdapat hal baru dari sebuah riset yang dilakukan dengan terciptanya hubungan-hubungan baru yang diharapkan akan dihasilkan temuan-temuan baru juga. 


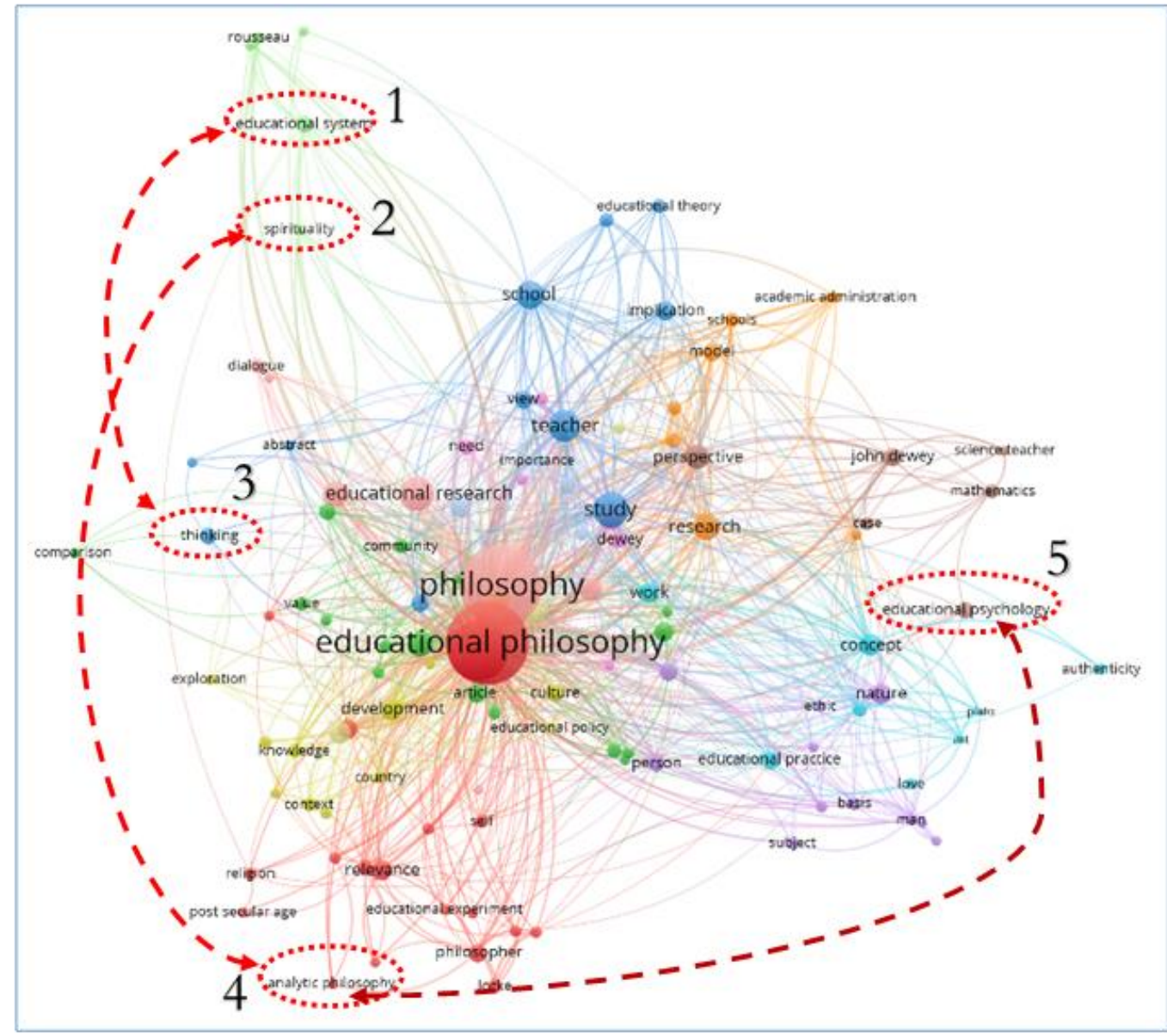

Gambar 9. Network visualization peta perkembangan penelitian filsafat pendidikan

Untuk menemukan di kluster mana sebuah istilah dan kata kunci berada, maka dapat dilakukan dengan proses maping antara Gambar 8 dengan Gambar 10 yang kemudian diplotkan pada Gambar 9. Sebagai contoh adalah istilah/kata kunci educational theory (33 kali kemunculan) masuk ke dalam kluster 3 dengan biru sebagai warna kluster. Selain network visualization perkembangan penelitian filsafat pendidikan, ditampikan juga overlay dan density visualization penelitian filsafat pendidikan yang dapat dijelaskan sebagai berikut. Pada overlay visualization dapat diketahui kebaruan tahun publikasi setiap artikel yang terbit berdasarkan kata kunci/istilahnya yang digambarkan dengan gradasi warna dari biru gelap ke kuning cerah, atau dengan kata lain menunjukkan jejak riwayat penelitian dari tahun ke tahun. Sebagai contoh untuk penelitian dengan istilah/kata kunci "analytic philosophy dan science teacher" yang berwarna kuning cerah. Dapat disimpulkan dua kata kunci ini diterbitkan di tahun 2020 sehingga merupakan artikel yang relatif baru dipublikasikan oleh penulisnya. Dengan melakukan analisis yang mendalam dari setiap kata kunci/istilah yang berwarna kuning pada overlay visualization, maka akan mengikuti tren-tren baru penelitian filsafat pendidikan di dunia. 


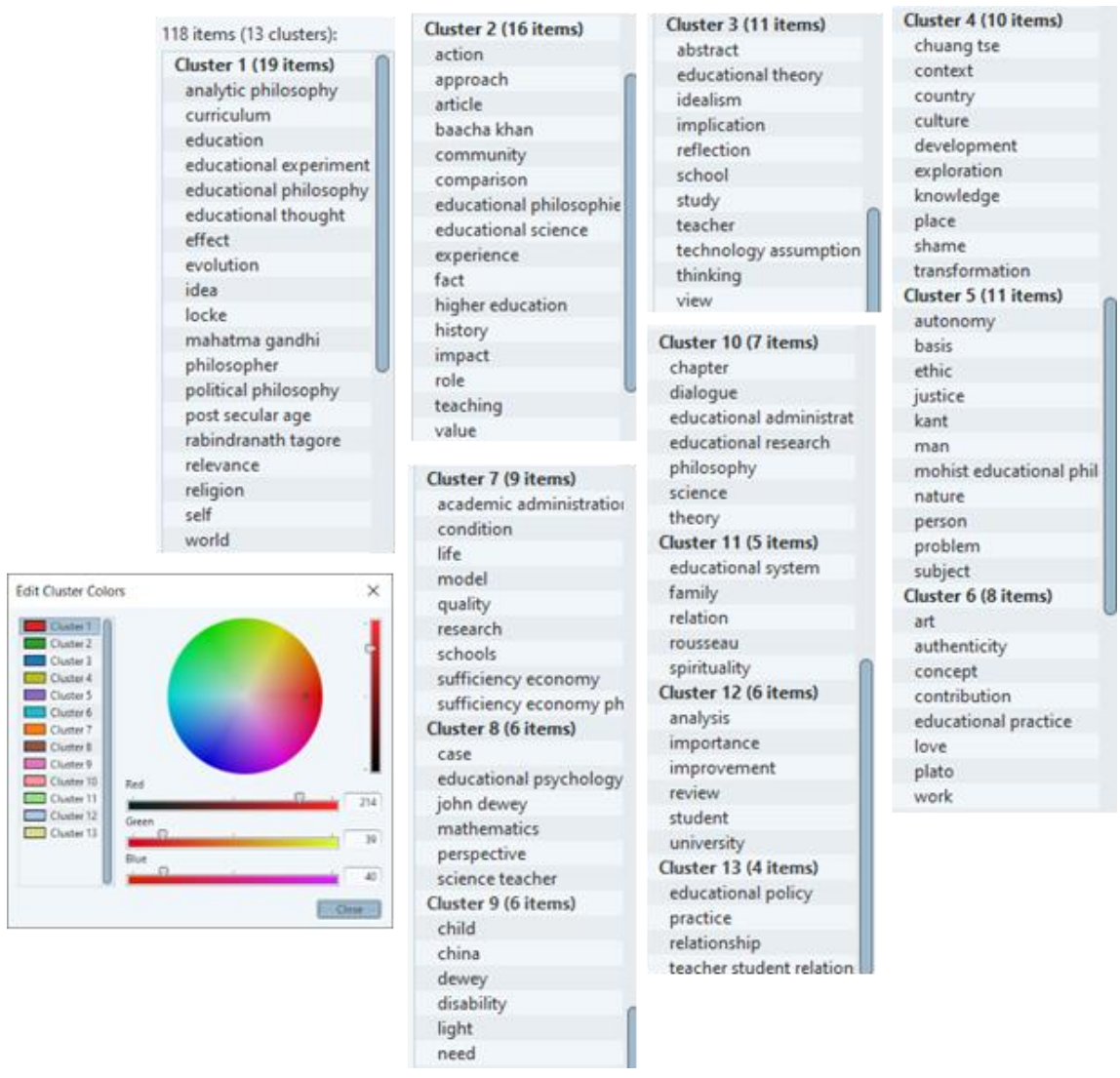

Gambar 10. Kluster kata kunci dan warna tiap cluster

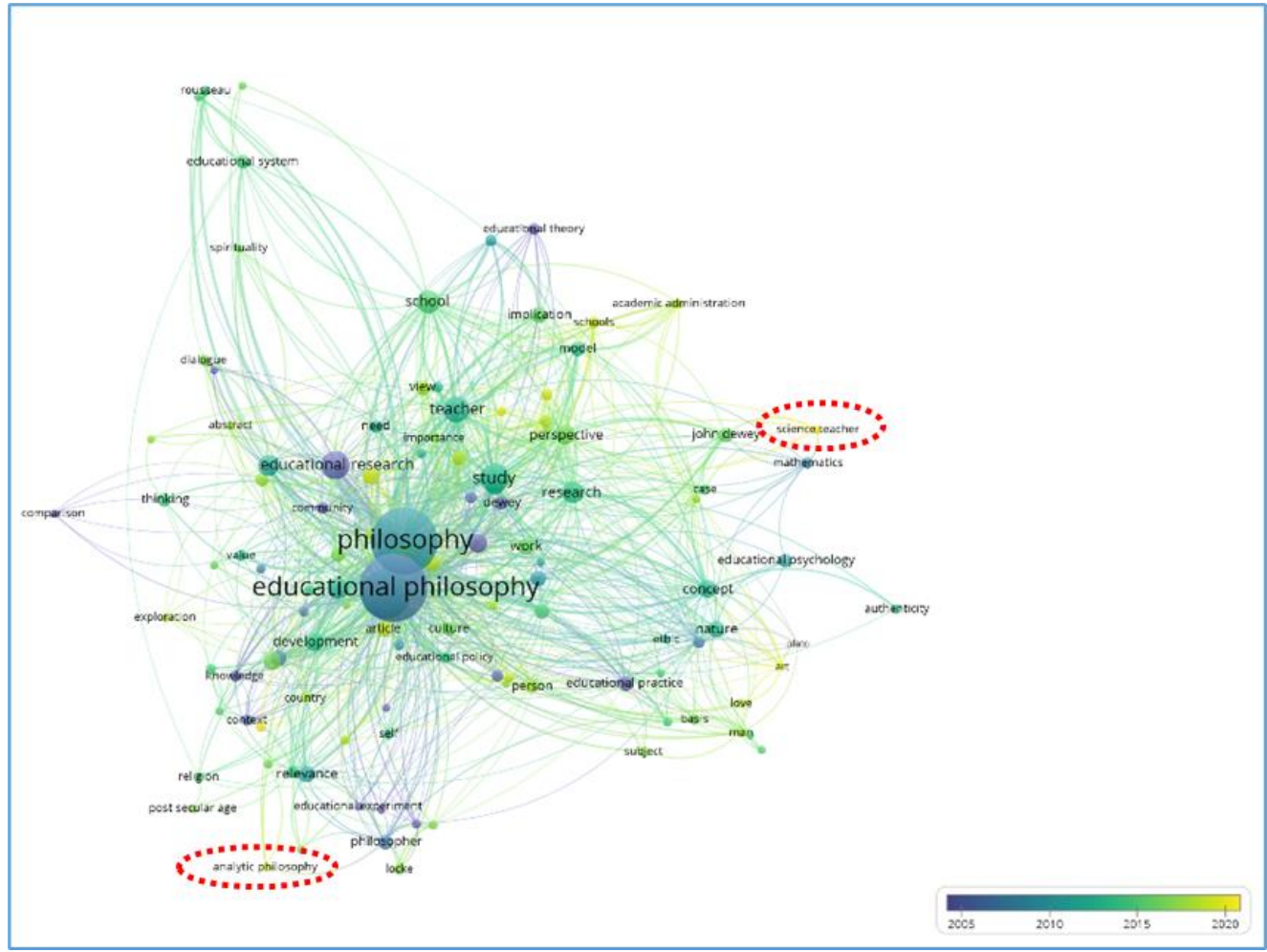

Gambar 11. Overlay visualization. 
Density visualization penelitian filsafat pendidikan hasil analisis VOSviewer ditunjukkan dalam Gambar 12. Density visualization menggambarkan kerapatan/penekanan pada kelompok penelitian (van Eck, Nees Jan, \& Waltman, 2013). Density dapat digunakan sebagai dasar untuk melihat topic-topik penelitian yang masih jarang dilakukan. Semakin pudar/kabur warnanya menggambarkan istilah-istilah/kata kunci/topik tersebut masih tidak banyak yang diteliti, sebaliknya jika warnanya semakin kuning cerah itu menandakan bahwa objek penelitian dengan topik tersebut sudah sering/sangat sering dilakukan. Contoh yang ditunjukkan dalam Gambar 12 adalah topic-topik yang masih jarang diteliti adalah yang dilingkari warna putih. Pada dua topik tersebut warna yang mendasarinya sangat pudar dan hampir tidak kelihatan. Dapat disimpulkan bahwa topik spirituality dan analytic philosophy memiliki kemungkinan menghasilkan kebaruan (novelty) yang tinggi jika dilakukan riset, sedangkan topik-topik dengan kata kunci philosophy dan educational philosophy mengalami kejenuhan penelitian karena sudah sangat banyak diteliti dengan ditunjukkan dengan warna yang kuning terang.

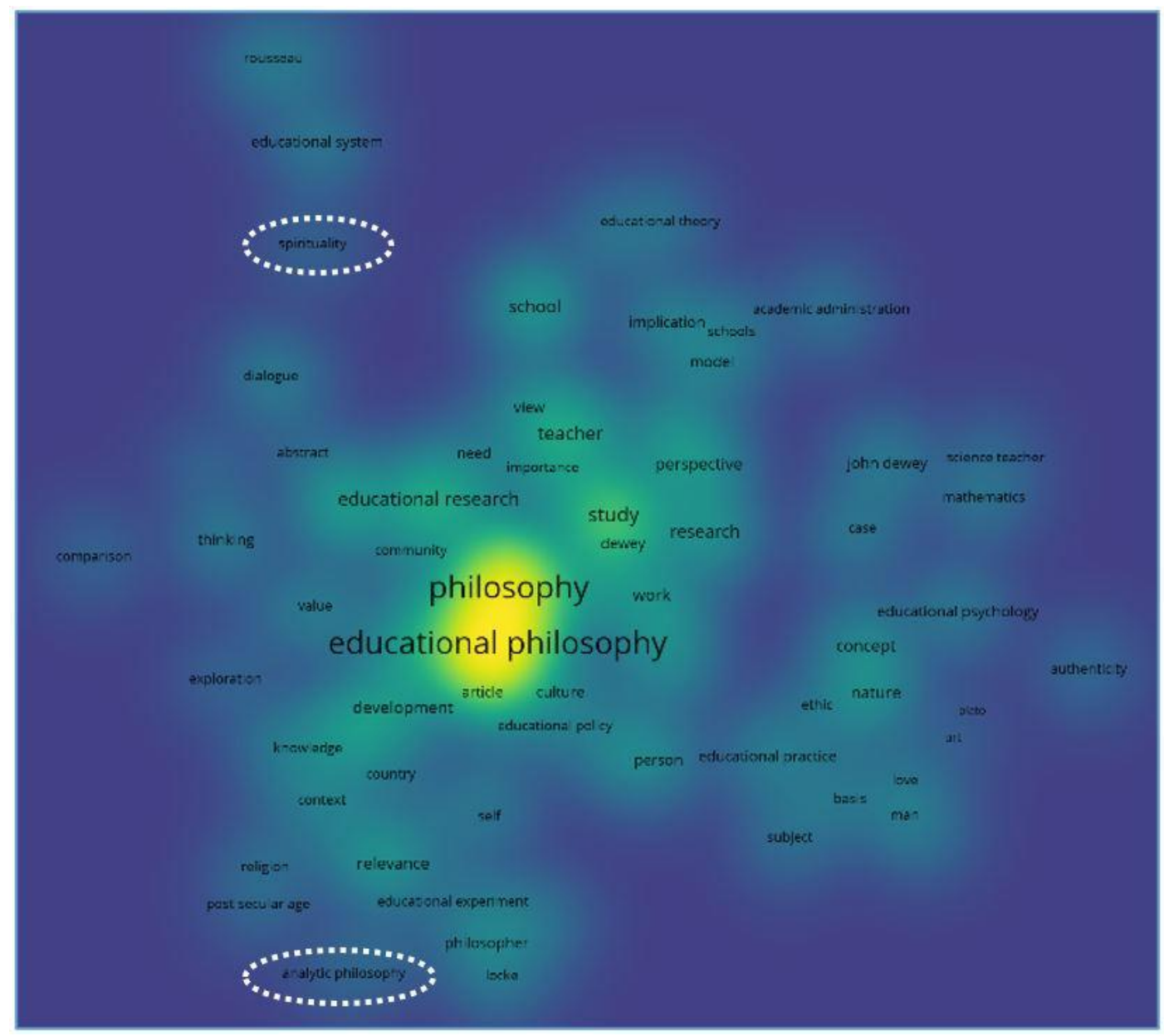

Gambar 12. Density visualization

\section{SIMIPULAN}

Secara garis besar perkembangan penelitian filsafat pendidikan mengalami tren yang meningkat dari tahun 1938 s.d 2020. Dari perkembangan penelitian filsafat pendidikan diperoleh informasi tentang evolusi perkembangan artikel dari database Scopus dari tahun 1938 s.d 2020, rangking Scimago JR, peringkat 10 besar (penulis, nama jurnal, judul artikel, dan sitasi artikel). Dengan VOSviewer dapat divisualkan beberapa analisis bibliometrik antara lain analisis co-authorship dan analisis co-word. Analisis bibliometrik memberikan gambaran dan pengetahuan tentang apa yang akan dilakukan untuk riset selanjutnya. Beberapa kata kunci/tema sebagai dasar penelitian selanjutnya didapatkan dalam analisis ini. Lebih jauh lagi penting untuk lebih memperdalam dan 
memperkaya hasil kajian pustaka yang dilakukan dengan menggunakan database yang lebih besar (terpercaya) dan mengembangkan kata kunci yang dipilih (dibandingkan-dianalisis-dielaborasi), menggunaan tools/software lain sejenis yang lebih baik seperti Citespace dengan fitur-fiturnya seperti Visual exploration of a research field, Structural and temporal overview, Finding hottopics and emerging trends, Cascading citation expansion, Systematic visual analysis of scientific literature, Intellectual landscape of a knowledge domain, serta selalu mengikuti perkembangan (update) keilmuaan topik yang dijadikan riset.

\section{DAFTAR RUJUKAN}

About Sherpa Romeo - v2.sherpa. (n.d.). Retrieved January 4, 2021, from https://v2.sherpa.ac.uk/romeo/about.html

Ang, W. L., Wahab Mohammad, A., Johnson, D., \& Hilal, N. (2019). Forward osmosis research trends in desalination and wastewater treatment: A review of research trends over the past decade. In Journal of Water Process Engineering (Vol. 31, p. 100886). Elsevier Ltd. https://doi.org/10.1016/j.jwpe.2019.100886

Baird, A. C. (1938). The educational philosophy of the teacher of speech. Quarterly Journal of Speech, 24(4), 545-553. https://doi.org/10.1080/00335633809380406

Beatty, J. E., Leigh, J. S. A., \& Lund Dean, K. (2020). Republication of: Philosophy Rediscovered: Exploring the Connections Between Teaching Philosophies, Educational Philosophies, and Philosophy. Journal of Management Education, 44(5), 543-559. https://doi.org/10.1177/1052562920912915

Björk, B. C. (2017). Open access to scientific articles: a review of benefits and challenges. Internal and Emergency Medicine, 12(2), 247-253. https://doi.org/10.1007/s11739-017-1603-2

Budapest Open Access Initiative | Ten years on from the Budapest Open Access Initiative: setting the default to open. (n.d.). Retrieved January 4, 2021, from https://www.budapestopenaccessinitiative.org/boai-10-recommendations

Christodoulou, M. (2020). Emancipation as subjectification. A critical realist reading of Biesta's educational philosophy. Journal of Critical Realism, 19(1), 14-28. https://doi.org/10.1080/14767430.2020.1715673

Dewey, J. (1944). Democracy and Education. The free Press a division of Mac Milland Publish Co, Inc.

Dewey, J. (2008). Pengalaman dan Pendidikan. Kepel Press. Directory of Open Access Journals (DOAJ). (n.d.). Retrieved January 4, 2021, from https://doaj.org/

E Fonseca, B. de P. F., Sampaio, R. B., Fonseca, M. V. de A., \& Zicker, F. (2016). Co-authorship network analysis in health research: Method and potential use. In Health Research Policy and Systems (Vol. 14, Issue 1, p. 34). BioMed Central Ltd. https://doi.org/10.1186/s12961-016-0104-5

Hidayat, R. (2013). Pedagogi Kritis. Raja Grafindo Persada.

Jarrah, A. M., Khasawneh, O. M., \& Wardat, Y. (2020). Implementing pragmatism and John Dewey's educational philosophy in Emirati elementary schools: Case of mathematics and science teachers. International Journal of Education Economics and Development, 11(1), 58-75. https://doi.org/10.1504/IJEED.2020.104287

Kelam, I., \& Rašić, L. (2020). The influence of Schopenhauer's and Nietzsche's philosophical thoughts on the philosophy of education and educational pessimism. Journal of Philosophy ARHE, 27(33), 243-265. https://doi.org/10.19090/ARHE.2020.33.243-265

Kuswana, W. S. (2013). Filsafat Pendidikan Teknologi, Vokasi dan Kejuruan. Alfabeta.

Morel, C. M., Serruya, S. J., Penna, G. O., \& Guimarães, R. (2009). Co-authorship Network Analysis: A Powerful Tool for Strategic Planning of Research, Development and Capacity Building Programs on Neglected Diseases. PLoS Neglected Tropical Diseases, 3(8), e501. https://doi.org/10.1371/journal.pntd.0000501

Mudyahardjo, R. (2008). Filsafat Ilmu Pendidikan. Rosdakarya.

Muhmidayeli. (2011). Filsafat Pendidikan. Refika Aditama.

Royani, Y., Bachtar, M. A., Tambunan, K., Tupan, T., \& Alm, S. (2013). Pemetaan karya tulis ilmiah LPNK: STUDI kasus LIPI DAN BPPT (2004-2008). Baca: Jurnal Dokumentasi Dan Informasi, 34(1), 1-28. https://doi.org/10.14203/J.BACA.V34I1.171

Setyaningsih, I., Indarti, N., \& Jie, F. (2018). Bibliometric analysis of the term "green manufacturing." International Journal of Management Concepts and Philosophy, 11(3), 315. https://doi.org/10.1504/ijmcp.2018.093500

Sidiq, M., Hanafi, I., \& Ekaputra, F. J. (2020). SEforRA: A Bibliometrics-ready Academic Digital Library Search Engine Alternative. KnE Social Sciences, 2020, 206-218-206-218. https://doi.org/10.18502/kss.v4i14.7877

Sierra-Henao, A., Muñoz-Villamizar, A., Solano-Charris, E., \& Santos, J. (2020). Sustainable development supported by industry 4.0: A bibliometric analysis. In Studies in Computational Intelligence (Vol. 853, pp. 366-376). Springer Verlag. https://doi.org/10.1007/978-3-030-27477-1_28

Taşkın, Z., \& Aydinoglu, A. U. (2015). Collaborative interdisciplinary astrobiology research: A bibliometric study of the nasa astrobiology institute. Scientometrics, 103(3), 1003-1022. https://doi.org/10.1007/s11192-015-1576-8

Tranfield, D., Denyer, D., \& Smart, P. (2003). No Title. British Journal of Management, 14(3), 207-222. https://doi.org/https://doi.org/10.1111/1467-8551.00375 
Tupan. (2016). Pemanfaatan Repositori Institusi Menuju Open Access : Studi Bibliometrik Dengan. Khizanah Al-Hikmah Jurnal Ilmu Perpustakaan, Informasi, Dan Kearsipan, 4(2), 104-117.

van Eck, Nees Jan, \& Waltman, L. (2010). Software survey: VOSviewer, a computer program for bibliometric mapping. Scientometrics, 84(2), 523-538. https://doi.org/10.1007/s11192-009-0146-3

van Eck, Nees Jan, \& Waltman, L. (2013). \{VOSviewer\} manual. Leiden: Univeristeit Leiden, November. http://www.vosviewer.com/documentation/Manual_VOSviewer_1.6.1.pdf

van Eck, Nees Jan, \& Waltman, L. (2014). Visualizing Bibliometric Networks. In Measuring Scholarly Impact (pp. 285320). Springer International Publishing. https://doi.org/10.1007/978-3-319-10377-8_13

Wikipedia. (2020). Internet traffic - Wikipedia. https://en.wikipedia.org/wiki/Internet_traffic

Yang, L., Chen, Z., Liu, T., Gong, Z., Yu, Y., \& Wang, J. (2013). Global trends of solid waste research from 1997 to 2011 by using bibliometric analysis. Scientometrics, 96(1), 133-146. https://doi.org/10.1007/s11192-012-0911-6

Ye, C. (2018). Bibliometrical analysis of international big data research: Based on citespace and vosviewer. ICNC-FSKD 2018 - 14th International Conference on Natural Computation, Fuzzy Systems and Knowledge Discovery, 927-932. https://doi.org/10.1109/FSKD.2018.8687153

Zupic, I., \& Čater, T. (2015). Bibliometric Methods in Management and Organization. Organizational Research Methods, 18(3), 429-472. https://doi.org/10.1177/1094428114562629 